\title{
A Review of the Relationship between Technological Innovation and Enterprise Value
}

\author{
Miao Tian ${ }^{1,2,3, a}$, Mu Zhang ${ }^{1, b,{ }^{*}}$ \\ ${ }^{1}$ School of Finance, Guizhou University of Finance and Economics, Guiyang Guizhou 550025, China \\ ${ }^{2}$ Guizhou Institute for Urban Economics and Development, Guizhou University of Finance and \\ Economics, Guiyang Guizhou 550025, China \\ ${ }^{3}$ Guizhou Institution for Technology Innovation \& Entrepreneurship Investment, Guizhou University \\ of Finance and Economics, Guiyang Guizhou 550025, China \\ a893806975@qq.com, brim_007@163.com \\ ${ }^{*}$ Corresponding author
}

Keywords: technological innovation, enterprise value, theoretical research, empirical analysis Abstract. In order to carry out further research on the relationship between technological innovation and enterprise value, this paper sorts out the main theoretical and empirical literature on the relationship between technological innovation and enterprise value.Mainly introduces the role of technological innovation, research the main theories on the relationship between technological innovation and enterprise value, an empirical study on the relationship between technological innovation and enterprise value, and makes a brief review of the relationship between innovation and enterprise, in order to grasp the technology of enterprise value better, enhance the value of the enterprise, and form their own core competitiveness, access the sustainable competitive advantage.

\section{Introduction}

Technological innovation is the premise and motive force of promoting enterprise value, enterprise value is the result of technological innovation capability and evaluation criteria, but lack of theoretical and systematic research result the segmentation in the practice.On the one hand, the relationship between technological innovation and enterprise value is fuzzy, innovation is difficult to reveal the value of the enterprise truly, the formation of technological innovation on the "black hole", on the other hand, the lack of enterprise value assessment to the lack of technological innovation evaluation standard and process management, it is difficult to form effective technological innovation value creation. This paper reviews the relevant literature about the relationship between technological innovation and enterprise value in recent years at home and abroad from two aspects of theory and empirical, unlock the relationships between the technological innovation and enterprise value in order to make the two effective combination, to enable enterprises to form a virtuous cycle of technological innovation and enterprise value, form their own core competitiveness, access the sustainable competitive advantage.

\section{Measurement and effect of technological innovation}

\section{Definition of technological innovation}

Technology innovation is the research and development of new technology or the application of existing technology innovation.From a higher level, technological innovation is a complete process from generation of new products or new technology ideas to market application, it includes new ideas, research, development, commercial production to spread such a series of activities, is essentially a science and technology, economic integration process, is the result of the interaction of technology development and application innovation, which includes the two aspects of technology development and technology application. 


\section{The role of technological innovation}

On the role of technological innovation for a business, many domestic and foreign literature have been studied.Most of them agree that technological innovation reduces the cost of production, improve the efficiency of the enterprise, and increase the economic efficiency of the enterprise.Guth (1990) believes that through technological innovation and development of new products and reduce the production cost of enterprises can improve the market competitiveness of products, can also open up new markets, enterprises formed a new profit growth point, so as to improve the ability of enterprises to obtain future income[1].Stopford (1994) believes that technological innovation is the core competitiveness of enterprises, but also the main factors driving business performance, to help enterprises to improve production and management capacity, obtain new core competence, so as to promote the growth of enterprises, improve the enterprise value [2].

\section{The relationship between technological innovation and enterprise value}

Through the collation of literature research on the relationship between technological innovation and enterprise value, that collected from relevant literature at home and abroad, when the relationship between technological innovation and enterprise value are theoretical research, but also part of the literature to analyze the relationship between technological innovation and enterprise value from the empirical part.

\section{Theoretical research on the relationship between technological innovation and firm value.}

When the relationship between technological innovation and enterprise value theory, it can be found that most of the literature direct theory to analyze the relationship between technological innovation and enterprise value, but also some literature is to grasp the relationship between technological innovation and enterprise value from the relationship between innovation capability and innovation performance.

\section{Technological innovation and enterprise value}

In the literature at home and abroad, the literature on the relationship between technological innovation and enterprise value is more and more in theory.Abroad, Myers (1977) on the relationship between growth opportunities and corporate value creation has made a substantial breakthrough in technological innovation, including the value of physical assets and the present value of future growth opportunities [3].Ben-Zion (1978) believes that the difference between the book value and the enterprise value is significantly related to the technology innovation capability [4].Srinivasan (2009) think that the enterprise technology innovation ability will have a positive impact on the performance of the enterprise, including the enterprise's market sales ability, enterprise financial position and enterprise value [5].At home, the king of the same law (2004) on the basis of modern enterprise value theory, analyzes the mechanism of value growth effect of technological innovation of enterprises, technological innovation makes the value of the enterprise is "normal growth", "growth" and "sustainable growth" [6].

\section{Innovation ability and innovation performance}

In the theoretical study of the relationship between technological innovation and enterprise value, some foreign scholars from the relationship between innovation capability and innovation performance to grasp the relationship between technological innovation and enterprise value.Kumar and Siddharthan (2002) in 213 Chinese industrial enterprises as the research object, the research of the correlation between the innovation ability and the innovation performance of these enterprises [7].Daniel I Prajogo (2006) to study the factors influencing the innovation, the relationship between innovation capability and innovation performance, the conclusion is: innovation performance and innovation ability, the relationship between innovation capability and innovation performance, and innovation effect relationship between factors and innovation performance is not obvious. He put 
forward the influence factors of innovation of entrepreneurs behavior, personnel, several aspects of knowledge and creativity [8].

\section{An empirical study on the relationship between technological innovation and firm value}

Most of the empirical studies are based on $R \& D$ expenditure, $R \& D$ input intensity as well as the number of enterprises patent as a proxy variable of technological innovation,explore the relationship between technological innovation and enterprise value. This can be divided into $R \& D$ expenditure and number of enterprises patent,$R \& D$ expenditure,number of enterprises patent, $R \& D$ expenditure and $R \& D$ Input intensity.

\section{$R \& D$ expenditure and Number of enterprises patent}

Using R \& D expenditure and the number of patents to empirical analysis of the relationship between technological innovation and enterprise value is the most commonly used method of scholars at home and abroad.Griliches (1981) shows that the intangible assets of firms with $R \& D$ expenditure and patent number as the proxy variables have a significant influence on the market value of enterprises [9].Bosworth and Rogers (2001) show that measuring $R \& D$ expenditure and patent number of enterprises' technological innovation has significant influence on Tobin's $Q$ value of enterprise value through research on data of large-scale enterprises in Australia [10].Yang and Chen (2003) used cross-sectional data from Chinese Taiwanese electronics firms to study the relationship between firm patents, $R \& D$ expenditure and market value in newly industrialized countries. Empirical results show that there is a significant correlation between the number of patents and the market value of Taiwanese electronics firms [11].

\section{Number of enterprises patent}

Empirical analysis of the relationship between technology innovation and enterprise value is also a method used by scholars to use the number of patents.Hirschey and Richardson (2001) to study the relationship between 1989-1995 years and 184 Japanese and 256 American high-tech enterprises patent quantity and market value of the enterprises, empirical evidence shows that the number of U.S. companies patent has a positive impact on the market value of the enterprise, but the relationship between the two companies in Japan was not significant [12]. While the effects of innovation on economic performance by Toivanen, Stoneman and Bosworth (2002) suggest that the number of patents does not have a significant impact on the firm's market value when $R \& D$ effects are taken into account [13].

\section{$R \& D$ expenditure}

There is little research on the relationship between technological innovation and enterprise value using a single $R \& D$ expenditure.Sundaram (1996) pointed out that the company's $R \& D$ spending forecast can predict the company's market value has a positive impact [14];Chauvin and Hirschey (1993)[15], Chan (1994)[16], Sundaram (1994) [17] have pointed out that the $R \& D$ expenditure announcement of listed companies has a positive impact on the company's stock and improves the value of the firm.

\section{$R$ \& $D$ Expenditure and $R$ \& $D$ Intensity}

Research on the $R \& D$ expenditure and $R \& D$ investment intensity is less, only Li Mengzhen (2015) take the panel data of 66 listed pharmaceutical companies in our country as the research object, The relationship between $R \& D$ expenditure, $R \& D$ input intensity and innovation environment support to enterprise value Tobin's Q value is analyzed,It is concluded that $R \& D$ expenditure and $R \& D$ investment intensity have significant effect on enterprise value, while innovation environment support has little effect on enterprise value [18].

\section{Brief comments}

At present, the less direct study of the relationship between technological innovation and enterprise value at home and abroad, research on the technology innovation and the enterprise value 
article less. Only research is mainly limited to theoretical analysis, micro empirical analysis especially for the empirical analysis of Chinese enterprises lack of systematic, and lack of resources as the logical starting point in the study of the relationship between the two the literature. However, the existing research results provides the foundation for good [19]. mechanism of small and medium enterprises value the project research on technology innovation of science and technology growth.

\section{Acknowledgement}

This work was financially supported by National Natural Science Foundation of China (71263011).

\section{References}

[1] Guth W. D, A Ginsberg. Guest editor's introduction: Corporate entrepreneurship[J]. Strategic Management Journal, 1990,19(1):24-25.

[2] Stopford J Baden Fulller C. Creating corporate entrepreneurship[J]. Strategic Management Journal, 1994,15(7):521-536.

[3] Myers S. Determinants of Corporate Borrowing[J]. Journal of Financial Economics, 1977

[4] Ben Zion, U. The investment aspect of non-production expenditure: An empirical test[J]. Journal of Economics and Business, 1978,30(3):224-229.

[5] Srinivasan Shuba, Dominique M Hanssens. Marketing and Firm Value: Metrics, Methods, Findings, and Future Directions[J]. Journal of Marketing Research, 2009,46(6):293-312.

[6] Wang Tong Lv. Technical innovation and enterprise value added value [J]. Journal of Zhongnan University of Economics and Law, 2004, (2): 126-131.

[7]Kumar, Siddharthan. Innovative Capability and performance of Chinese firms[J]. Journal of Development Studies, 2002, (2):59-67.

[8]Daniel I Prajogo, Pervaiz K. Ahmed. Relationships between innovation stimulus, innovation capacity and innovation performance[J]. R\&D Management, 2006,36(5):499-515.

[9]Griliches Z. Market value, R\&D and patent[J]. Economics Letters, 1981,7(2):183-187.

[10]Bosworth D, Rogers M. Market value, R\&D and intellectual property: an empirical analysis of large Australian firms[J]. The Economic Record, 2001,77(239):323-337.

[11] Chen Xiude, Peng Yulian, Lu Chunyuan. Empirical research of [J]. science Chinese relationship between technological innovation and business value of listed companies, 2011,29 (1): 138-146.

[12]Toivanen O, Stoneman P, Bosworth D. Innovation and the market value of UK firms, 19891995[J]. Oxford Bulletin of Economics and Statistics, 2002,64(1):39-61.

[13]Yang C H, Chen J R. Innovation and market value in Newly-Industrialized countries: the case of Taiwanese electronics firms[J]. Asian Economic Journal, 2003,17(2):205-220.

[14]Sundaram A K. John K. An empirical analysis of strategic competition and values the case of R\&D competition[J]. Joumal of Financial Econmics, 1996,44(1):129-161.

[15]Chauvin K W, Hirschey M. Advertising, R\&D expenditures and the market value of the firm[J]. The Journal of the Financial Management Association, 1993,22(4):128-131.

[16]Chan C, Swift F, Lee S, et al. Development of a feature-based and object-oriented concurrent engineering system[J]. Journal of Intelligent Manufacturing, 1994,5(1):23- 31. 
[17]Sundaram A K, John T A, John K. An empirical analysis of strategic competition and firm values: the case of R\&D competition[J]. Journal of Financial Economics, 1996,44(1):129- 161.

[18] Li Mengzhen, Qiu Jiaxue. [J]. modern commerce industry, technology innovation ability of China's pharmaceutical enterprises to enterprise value influence 2015, (8): 1-4.

[19] Li Na, Li Jianhua, Xiao on technological innovation ability and enterprise value. -- a review on research [D]. Jilin: Jilin University, 2010,(6)91-94. 